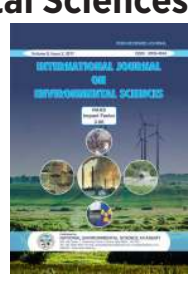

\title{
HYDROBIOLOGICAL STUDY OF BURHI GANDAK RIVER NEAR URBAN AREA AT SAMASTIPUR (BIHAR)
}

\author{
Sarvesh Kumar \\ Department of Zoology, Samastipur College, Samastipur \\ L. N. Mithila University, Darbhanga Bihar
}

Research Article

Received: 01.06.2020

Revised: 15.06.2020

Accepted: 30.06 .2020

\begin{abstract}
Hydrobiological studies of Burhi Gandak river were carried out for a period of one year from March, 2019 to February, 2020 at two stations of urban area of Samastipur town, Bihar. The parameters taken included the water temperature, transparency, $\mathrm{pH}$, dissolved oxygen, magnesium, and calcium. These properties were analyzed and compared with standard values recommended by bureau of Indian standards and world health organization. Present investigation was undertaken to ascertain the water quality status of Burhi Gandak river at Samastipur town. The results revealed that there were significant seasonal variations in most of the parameters; water was found to be hard, polluted and not suitable for domestic, agricultural and fish growth.
\end{abstract}

Keywords: Hydrobiological status, Burhi Gandak river, Fish culture.

\section{INTRODUCTION}

Rivers are vital and vulnerable freshwater systems that are critical for the sustenance of all lives. However, the declining quality of the water in these systems threatens their sustainability and is therefore a cause for concern. Rivers are waterways of strategic importance across the world, providing main water resources for domestic, industrial and agricultural purposes (Prakash et al., 2020). The maintenance of healthy aquatic ecosystem is required for ecological balance and agriculture (Verma, 2018a, 2018b), which depends on good physico-chemical properties of water. India is gifted with a river system comprising more than 20 major rivers with several tributaries and more than $50 \%$ of water resources of
India are located in various tributaries of these river systems (Lal, 2001). North Bihar is very rich in water resources. Burhi Gandak is one of the major rivers in Samastipur district of North Bihar. The people in and around the Samastipur area use the water of this river for various purposes such as irrigation, bathing, washing drinking. Apart from these human activities, domestic sewage also discharges of into river. As a result the water quality has been affected. Industrial revolution has led to change in river water chemistry to the extent that very few are now in natural condition.

Although a large number of workers have studied the physico-chemical and biological parameters as well

*Corresponding author: sarveshzoology@gmail.com 
as fish diversity of fresh water bodies including Rao (1977), Prakash (2020), Prakash et al., (2002), Singh and Verma (2016), Sugumaran et al., (2020),Verma (2016, 2017, 2018c, 2019, 2020), Verma and Prakash (2018, 2020a), Bhagde et al., (2020) but till now there is no sufficient baseline data about physicochemical parameters of Burhi Gandak river at Samastipur. Therefore, the present work was undertaken to study the hydrobiological characteristics of Burhi Gandak River in relation to fisheries and pollution. Purpose of the study was not only to enhance the hydobiological condition of river but also to explore the possibilities for better management and development.

\section{MATERIALS AND METHODS}

The River Burhi Gandak is a so-called "plainsfed" river originates from Chautarwa Chaur in the Someshwar range of hills at $300 \mathrm{~m}$ above mean sea level near Bishambharpur in the West Champaran district in Bihar. The main River course lies entirely in Bihar in Indian Territory. However, some left bank tributaries of the Sub-basin flow through Nepalese Territory. The total catchment of the Sub-basin is $12,500 \mathrm{~km}^{2}$, out of which 2,350 $\mathrm{km}^{2}$ lies in Nepal.

Two sampling stations were selected stations I (Urban area of Samastipur town) near Laxmitakies and Station II (Bahadurpur) near Petrol pump for study the Physico-chemical and Biological characteristics of the river water. The water samples were collected from both stations in morning between 8.30 and 9.30 a.m. during the period of March 2019 to February 2020. Water was collected using sterile glass stopped bottles and $2 \mathrm{~L}$ capacity plastic bottle. The estimation of various physico-chemical parameters was done following standard methods described by APHA (2005).

\section{RESULT AND DISCUSSION}

The water quality parameters for selected sampling sites are presented in Table.1-2.

Table 1: Physico-chemical characteristics of Burhi Gandak River water at Station-I \&II.

\begin{tabular}{|l|c|c|c|c|c|c|c|c|c|c|c|c|}
\hline \multirow{2}{*}{ Month } & \multicolumn{2}{|c|}{ Temp. (0C) } & \multicolumn{2}{c|}{ Trans. (mg/l) } & \multicolumn{2}{c|}{ pH } & \multicolumn{2}{c|}{ DO (mg/l) } & \multicolumn{2}{c|}{ Mg (mg/l) } & \multicolumn{2}{c|}{ Ca (mg/l) } \\
\cline { 2 - 13 } & S-I & S-II & S-I & S-II & S-I & S-II & S-I & S-II & S-I & S-II & S-I & S-II \\
\hline Mar. & 24.0 & 24.1 & 15.3 & 23.1 & 8.2 & 7.8 & 7.2 & 8.4 & 22.0 & 17.4 & 38.5 & 31.2 \\
\hline Apr. & 25.0 & 24.0 & 16.8 & 24.6 & 8.0 & 7.6 & 6.3 & 7.1 & 24.5 & 21.2 & 34.5 & 20.1 \\
\hline May. & 32.5 & 31.6 & 18.0 & 25.9 & 7.5 & 7.4 & 5.2 & 6.1 & 28.2 & 22.5 & 16.1 & 15.4 \\
\hline Jun. & 30.0 & 30.2 & 16.5 & 22.2 & 7.7 & 7.5 & 5.1 & 6.1 & 26.2 & 21.4 & 19.5 & 20.0 \\
\hline Jul. & 31.5 & 31.0 & 14.5 & 20.0 & 7.5 & 7.3 & 4.6 & 5.3 & 24.3 & 18.3 & 21.5 & 22.2 \\
\hline Aug. & 30.5 & 29.2 & 9.0 & 11.2 & 8.0 & 7.6 & 4.8 & 5.6 & 19.0 & 15.0 & 25.0 & 24.5 \\
\hline Sep. & 28.0 & 27.5 & 9.5 & 15.0 & 8.1 & 7.6 & 6.1 & 5.7 & 18.2 & 16.3 & 27.5 & 27.5 \\
\hline Oct. & 22.5 & 22.0 & 10.5 & 18.5 & 8.4 & 7.8 & 7.0 & 5.9 & 18.4 & 17.1 & 31.5 & 30.0 \\
\hline Nov. & 19.0 & 18.6 & 14.0 & 21.4 & 8.3 & 8.1 & 8.4 & 7.8 & 19.1 & 17.3 & 39.5 & 38.5 \\
\hline Dec. & 18.5 & 19.4 & 14.5 & 22.0 & 8.5 & 8.0 & 9.0 & 9.5 & 20.2 & 16.7 & 42.0 & 40.0 \\
\hline Jan. & 19.0 & 18.4 & 15.5 & 23.1 & 9.5 & 8.2 & 9.1 & 10.0 & 20.3 & 18.4 & 43.0 & 41.0 \\
\hline Feb. & 18.5 & 18.5 & 14.0 & 22.1 & 7.5 & 8.1 & 7.6 & 8.2 & 20.5 & 18.5 & 41.5 & 39.0 \\
\hline
\end{tabular}


Temperature measurement is an important aspect of water quality assessment as it not only determines the solubility of different gases in the water but also affects certain biochemical reactions taking place in the aquatic organisms (Singh and Singh, 2020). The temperature was ranged between 18.5 to $32.5^{\circ} \mathrm{C}$ at station-I and 18.5 to $31.6^{\circ} \mathrm{C}$ at station-II. The maximum temperature was recorded as $33.5^{\circ} \mathrm{C}$ at station-I in the month of May and minimum was recorded as $18.5^{\circ} \mathrm{C}$ at both station in the month of February. In summer months, water temperature was generally higher as compared to winter months (Prakash $e t$ al., 2015). Fluctuation in air temperature had direct impact on water temperature (Welch, 1952). The range of water temperature was within the optimum range and suitable for the development and growth of fish (Jhingran, 1988).

The average depth at which Sachhi disc disappears and again reappears from open surface of water is called transparency of water. It is inversely proportional to the turbidity of water (Kumar et al., 2015). Water transparency controls the energy relationship at different trophic levels in food chain (Kumari and Jha 2015). The transparency was ranged between $9.0-18.0 \mathrm{~cm}$ at station-I and 11.2 to $25.9 \mathrm{~cm}$ at station-II. Maximum transparency was noted during winter, low in summer and lowest in the rainy months. Maximum transparency recorded during winter months may be attributed to sedimentation of suspended matter as opined earlier (Chaurasia and Adoni,1985).

The $\mathrm{pH}$ value was varied between of 7.3 and 9.5. The minimum $\mathrm{pH}$ was recorded 7.3 at station-II while maximum 9.5 at station-I. This value is within permissible limits as per prescribed by world health organization. Alkalinity range of river water is indicative of the fact that photosynthetic activity has dominance over the respiratory activity of the biota (Ansari and Prakash, 2000). The $\mathrm{pH}$ of water ranged between 7.3 and 9.5 which show the favorable conditions of productivity of fishes.

Dissolved oxygen level in the three sampling sites was ranged between 4.6 to $10.0 \mathrm{mg} / \mathrm{l}$. It was maximum $(10.0 \mathrm{mg} / \mathrm{l})$ at station-II in winter month and was minimum $(4.6 \mathrm{mg} / \mathrm{l})$ at station-I. The high range of dissolved oxygen was found in winter months. The fish needs at least $5 \mathrm{mg} / \mathrm{l}$ dissolved oxygen therefore the water of river is suitable for development and growth of fish (Verma, 2020).

Magnesium is a most abundant ion in fresh water and is absolutely essential for chlorophyll bearing algae and other plants. The range of fluctuation of magnesium in both stations is $15.0-28.2 \mathrm{mg} / \mathrm{l}$. An almost similar range of variation has also been reported by Agrawal et al. (1997).

Calcium is an important nutrient for aquatic organisms. The calcium level was ranged between $16.1-43.0 \mathrm{mg} / \mathrm{l}$. It is found to be low in monsoon and high in winter season which could be due to its higher solubility at low temperature (Ansari and Prakash, 2000). The low calcium content present in the water resource may be responsible for maintaining normal hardness level. Maximum calcium was observed at stationI in the winter months. The minimum value of calcium was recorded at station-I in the monsoon months.

Table 3: Biological characteristics of River Burhi Gandak River water at Station-I \& II.

\begin{tabular}{|l|l|l|}
\hline Group & Sampling station I & Sampling station II \\
\hline Balillariophyceae & $48 \%$ & $39 \%$ \\
\hline Chanophycae & $45 \%$ & $51 \%$ \\
\hline Chlorophyceae & $5 \%$ & $7 \%$ \\
\hline
\end{tabular}


The percentage of chlorophyceae varied from station I and II. During the rainy season there was a sharp fall in phytoplankton density \& primary productive.

Burhi Gandak River is important part of nature and water quality should be maintained. Water quality of BurhiGandak clearly indicates rise in calcium \& magnesium content at station I. It also indicates slight high temperature in comparison with observation site II, fall in transparency. This observation is similar to that observed by various workers (Bohra and Kumar 1995), Mohammad et al. (2003), Chaturvedi and Pandey (2006) also observed seasonal variation in the biomodal pattern in Physico-chemical parameters. The Physico-chemical quality of water, fauna and flora at each station was examined to determine the diversity, density and distribution of aquatic life. Low diversity of fish and macro invertebrates was the indication of pollution.

\section{ACKNOWLEDGMENT}

Author is thankful to Principal and Head of the department of Zoology, Samastipur college, Samastipur for providing laboratory facilities.

\section{REFERENCES}

1. Agrawal, P., Sharma, K. and Singh, P. P. (1997). Fish culture in derelict berick-kiln land area. J. Environ. Biol. 18(1):43-49.

2. Ansari, K.K. and Prakash, S. (2000). Limnological studies on Tulsidas Tal of tarai region of Balrampur in relation to fisheries. Poll. Res. 19(4): 651-655.

3. APHA (2005). Standard methods for Examination of water and waste water. American Public Health Association 21st Ed. APHA, New York.

4. Bhagde R. V., Pingle S. A., Bhoye M. R., Pansambal S. S. and Deshmukh D. R. (2020). A Comparative Study of PhysicoChemical Parameters of the Freshwater Ponds from Sangamner Taluka of
Ahmednagar, Maharashtra, India. International Journal of Biological Innovations. 2(2): 137-142.

5. Bohra, C. and Kumar A. (1995) Modeling of pollution load assessment of fresh water lotic ecosystem. Indian J. Environ Bioth 37: 37-48.

6. Chaturvedi, J. and Pandey, N.K., 2006 Physico-chemical analysis of river Ganga at VindhyachalGhat Current world Environment (2): 177-179.

7. Chaurasia, S.K. and Adoni, A.D. (1985) Zooplankton dynamics in a shallow eutrophic lake. Proc. Nat. symp. Pure Appl. Limnology Bot. SOC. Sagar.32.30-39.

8. Kumar, U., Choudhary, S., Kumar, M. and Paswan, R. (2015): Physico-chemical Prameters of Gamhi water body of the Kaula Chaur (Wetland) of Begusarai District (Bihar). Proc. Zool. Soc. India. 14(1):1-6.

9. Kumari, C. and B. K. Jha (2015): Health status of lentic water bodies of Twin-City of Darbhanga-Laheriasari (Bihar) with reference to seasonal variation in the physicchemical characteristics. Proc. Zool. Soc. India. 14(1):7-14.

10. Jhingran, V.G. (1988). Fish and fisheries of India. Hindustan Publishing Corporation, India,pp666.

11. Lal, M. (2001). Climate changeImplications for India's water resources. $J$. India Water Res. Soc. 21: 101-119.

12. Mohamad AH, Abdus Salam, Jamshid and Targeted Zahra (2003): Studies in Biodiversity in seasonal variation in water of river Indus at Ghazi Ghat, Punjab, Pakistan, Journal of Biology science, 6(21)1840-1844.

13. Prakash, S. (2001). Utilization of BrickKiln land in aquaculture. GEOBIOS. 28(4):193-196. 
14. Prakash S. (2020). Fish diversity of Semara Taal, a wetland of district Siddharthnagar (U.P.), India. International Journal of Fisheries and Aquatic Research. 5(2):07-09.

15. Prakash S., Kumar A., Prakash S. and Mishra B.K. (2020). A Survey of Fish Fauna of Rapti River, Balrampur (U.P.), India. International Journal of Biological Innovations. 2(1): 76-81.

16. Prakash S., Verma A.K., and Prakash S. (2015). Limnological Studies of Alwara Lake of Kaushambi (U.P.). International Journal on Biological Sciences. 6 (2): 141144.

17. Prakash S., Ansari K.K. and Sinha M. (2002). Seasonal dynamics of Zooplankton in a fresh water pond developed from the wasteland of Brick-kiln. Poll. Res. 21(1): 82-83.

18. Rao V.S. (1977): An ecological study of three fresh water ponds of Hyderabad, India. Hydrobiologia. 53:13-23

19. Singh S. and Singh S. (2020). Macrophytes as Bioindicator in Bichhiya River, Rewa (M.P.), India. International Journal of Biological Innovations. 2(1): 25-30.

20. Singh P. R. and Verma A. K. (2016). Observations on Hydrobiological Conditions of River Ganga at Daraganj, Allahabad. The Journal of Zoology Studies. 3(4): 81-82.

21. Sugumaran E., Shabeen B. and Radhakrishnan M.V. (2020). Zooplankton Diversity in Sathanur Reservoir of Thiruvannamalai (Tamilnadu), India. International Journal of Biological Innovations. 2 (2): 95-101.

22. Verma A.K. (2016). Hydrobiological Studies of Muntjibpur Pond of Allahabad (U.P.). International Journal on Agricultural Sciences. 7 (2): 164-166.
23. Verma A.K. (2017). Distribution and conservation status of fishes reported from Muntjibpur pond of Allahabad (U.P.). International Journal of Scientific World. 5(1): 50-52.

24. Verma A.K. (2018a). Unsustainable Agriculture, Environmental Ethics and Ecological Balance. HortFlora Research Spectrum. 7 (3): 239-241.

25. Verma A.K. (2018b). Ecological Balance: An Indispensable Need for Human Survival. Journal of Experimental Zoology India. 21 (1): 407-409.

26. Verma A.K. (2018c). A Biodiversity Survey of Muntjibpur Pond of District Allahabad (U.P.). International Journal on Environmental Sciences. 9(1):56-59.

27. Verma A.K. (2019). Studies of Hydrobiological Properties of Balapur Pond of Prayagraj (U.P.). Hortflora Research Spectrum. 8(1): 9-11.

28. Verma A. K. (2020). Limnological Studies of Muntjibpur pond of Prayagraj (U.P.) in relation to planktons. International Journal of Fauna and Biological Studies. 7 (4): 2730.

29. Verma A. K. and Prakash S. (2018). Qualitative and quantitative analysis of macrozoobenthos of Beghel Taal, a wetland of U.P. Indian Journal of Biology. 5 (2): 127-130.

30. Verma A. K. and Prakash S. (2020a). Limnological Studies on Semara Taal, A wetland of District Siddharthnagar, Uttar Pradesh, India. Journal of Fisheries and Life Sciences. 5(1): 15-19.

31. Verma A. K. and Prakash S. (2020b). Zooplankton Diversity in Guthia Taal, Wetland of Bahraich (U. P.), India. International Journal of Zoology and Research. 10(2):09-18.

32. Welch P.S. (1952): Limnology II $^{\text {nd }}$ edition McGrew Hill Book Co., N.Y., 536 pp. 